\title{
PENJAMINAN TERHADAP SIMPANAN NASABAH YANG TIDAK DIJAMIN OLEH LEMBAGA PENJAMIN SIMPANAN PADA BANK YANG TERLIKUIDASI*
}

Oleh:

\author{
Gusti Ayu Oka Dwi Astari** \\ I Ketut Westra** \\ Program Kekhususan Hukum Bisnis Fakultas Hukum \\ Universitas Udayana
}

\begin{abstract}
ABSTRAK
Penulisan jurnal ini dilatar belakangi oleh mekanisme pengembalian dana simpanan nasabah yang tersimpan pada bank yang dilikuidasi. Simpanan yang dimaksud yaitu simpanan yang tidak dijamin oleh Lembaga Penjamin Simpanan. Dari latar belakang permasalahan tersebut, kemudian penulis angkat sebagai permasalahan sekaligus tujuan dari penulisan jurnal ini yaitu bagaimana tanggung jawab bank atas simpanan nasabah yang tidak mendapatkan jaminan LPS, serta bagaimana upaya penyelesaian yang dilakukan oleh pihak bank yang dalam hal ini yaitu BPR Swasad Artha dengan nasabah penyimpan. Metode penelitian yang digunakan dalam penulisan jurnal ini adalah metode penelitian hukum empiris, yaitu melalui pendekatan perundang-undangan, pendekatan fakta, pendekatan analitis dan konseptual. Sumber data yang digunakan dalam penulisan skripsi ini berasal dari data primer dan data sekunder. Data primer yaitu data yang diperoleh dari penelitian di lapangan yang berasal dari narasumber. Data sekunder berasal dari penelitian kepustakaan. Kesimpulan tulisan ini yaitu pertama tanggung jawab bank terhadap simpanan nasabah yang tidak dijamin oleh LPS yaitu bank melakukan pengembalian dana kepada nasabah yang tidak mendapatkan jaminan oleh LPS sebagai bentuk pertanggungjawaban bank. Kedua, upaya yang dilakukan dalam penyelesaian simpanan nasabah yang menjadi tanggung jawab bank, dalam hal ini, para pihak menempuh jalur nonlitigasi yaitu dengan melakukan negosiasi.
\end{abstract}

* Penulisan Karya Ilmiah berjudul Penjaminan Simpanan Nasabah yang Tidak dijamin oleh Lembaga Penjamin Simpanan pada Bank yang Terlikuidasi merupakan ringkasan skripsi penulis.

** Gusti Ayu Oka Dwi Astari, 1503005202, Mahasiswa S1 Reguler Pagi, email dwiastari.gusti@gmail.com

*** Dr. I Ketut Westra, SH., MH, dosen Tetap Fakultas Hukum Universitas Udayana. 


\title{
Kata Kunci: Bank Likuidasi, Lembaga Penjamin Simpanan, Nasabah Penyimpan
}

\begin{abstract}
The writing of this journal is motivated by the mechanism of returning and depositing customers stored in liquidated banks. Deposits in question are deposits that are not guaranteed by the Deposit Insurance Corporation. From the background of the problem, then the author adopts the problem as well as the purpose of writing this journal, namely how bank responsibility is for deposits that do not receive LPS guarantees, as well as how the settlement is carried out by the bank, in this case BPR Swasad Artha with depositing customers. The method of research used in writing this journal is the method of empirical legal research, which is through legislative approaches, factual approaches, analytical and conceptual approaches. The data sources used in writing this essay are from primary and secondary datasets. Primary data is data obtained from research in the field from sources. Secondary data comes from library research. The conclusion of this paper is that the bank's first responsibility for customer deposits that are not guaranteed by LPS is that the bank makes a refund to customers who do not get a guarantee by LPS as a form of bank accountability. Second, the efforts made in settling customer deposits which are the responsibility of the bank, in this case, the parties take a nonlitigation path, namely by conducting negotiations.
\end{abstract}

Keywords: Liquidation Bank, Deposit Insurance Agency, Depositors

\section{PENDAhUluan}

\section{I.1. Latar Belakang Masalah}

Industri perbankan merupakan salah satu komponen yang sangat penting didalam kelangsungan perekonomian nasional. Hal ini dikarenakan setiap negara tidak dapat terlepas dari lalu lintas pembayaran dimana industri perbankan memegang peranan yang sangat strategis didalam menjadi pusat perekonomian negara. ${ }^{1}$

1 Jonker Sihombing, 2010, Penjamin Simpanan Nasabah Perbankan, Alumni, Bandung, hlm.1 
Sesuai dengan prinsip yang berlaku secara umum, setiap bank wajib untuk menjamin simpanan nasabah yang disimpan dalam bank tersebut. Pasal 37 B UndangUndang No. 7 Tahun 1992 sebagaimana telah diubah dengan Undang-Undang No. 10 Tahun 1998 menegaskan bahwa untuk menjamin simpananmasyarakat yang ada di bank, akan dibentuk Lembaga Penjamin Simpanan (LPS). Selanjutnya, dalam Pasal $37 \quad$ B tersebut juga diatur bahwa Lembaga Penjamin Simpanan akan diatur lebih lanjut dalam peraturan pemerintah. ${ }^{2}$

Sebagai bentuk tindak lanjut dari pengaturan mengenai kewajiban bank untuk menjamin dana masyarakat, ditentukan dalam Pasal 37 B Undang-Undang Perbankan, yaitu tentang perlunya pembentukan Lembaga Penjamin Simpanan, pada tahun 2004 pemerintah membentuk suatu badan khusus yang disebut Lembaga Penjamin Simpanan atau LPS. Pembentukan badan khusus ini dilakukan melalui Undang-Undang No. 24 Tahun 2004 tentang Lembaga Penjamin Simpanan (selanjutnya disingkat menjadi UU LPS). Pasal 4 UU LPS menentukan, bahwa fungsi LPS adalah menjamin simpanan nasabah penyimpan dan turut aktif dalam memelihara stabilitas sistem perbankan sesuai dengan kewenangan yang dimilikinya.

Perkembangan pesat dalam industri perbankan di Provinsi Bali khususnya mengakibatkan timbulnya persaingan yang ketat antara BPR, Bank Umum maupun Lembaga keuangan mikro lainnya. Hal ini menimbulkan adanya beberapa BPR yang tidak mampu untuk menjalankan fungsinya dengan baik sehingga menyebabkan kesehatan BPR tersebut terganggu yang berujung pada proses likuidasi.

2 Kusumaningtuti SS, 2008, Peranan Hukum Dalam Penyelesaian Krisis Perbankan di Indonesia, Rajawali Pers, Jakarta, hlm. 64 
Bank yang dilikuidasi membuat sebagian masyarakat khawatir akan keberadaan dana simpanannya itu akan kembali atau bahkan hilang. Hal itu tidak lain karena banyak dari masyarakat hanya tahu menabung, berbunga, lalu mereka menariknya kembali, dengan tidak mengetahui hak-haknya sebagai penyimpan dana. Bank yang mengalami likuidasi tersebut, bagaimanakah nasib para nasabah yang menyimpan uangnya pada bank bersangkutan yang melebihi besaran angka yang dijamin oleh LPS. ${ }^{3}$ Hal ini menimbulkan suatu permasalahan ketika bank mengalami likuidasi dan harus mengembalikan dana nasabah yang menyimpan dananya pada bank bersangkutan khususnya pada BPR Swasad Artha yang telah mengalami likuidasi dan dicabut ijin usahanya oleh BI pada tahun 2010. Berdasarkan uraian di atas, maka penulis tertarik membahas mengenai penjaminan terhadap simpanan nasabah yang tidak dijamin oleh lembaga penjamin simpanan pada bank yang terlikuidasi.

\section{I.2. Rumusan Masalah}

Berdasarkan latar belakang diatas, maka permasalahan yang akan dibahas adalah sebagai berikut:

1. Bagaimanakah tanggung jawab bank terhadap nasabah penyimpan atas simpanannya yang tidak dijamin oleh Lembaga Penjamin Simpanan?

2. Bagaimanakah upaya bank dalam penyelesaian simpanan nasabah yang simpanannya melebihi jumlah

${ }^{3}$ Ni Made Dasri Librayanti, Made Mahartayasa, 2014, Kewenangan Lembaga Penjamin Simpanan dalam Likuidasi Bank, Jurnal Hukum Udayana, Vol. 02, No. 02,Februari 2014.

Url: https:/ / www.e-jurnal.com/2014/12/kewenangan-lembaga-penjaminsimpanan.html Diakses pada tanggal 26 Februari 2019, pukul 17.30 
penjaminan oleh Lembaga Penjamin Simpanan setelah terjadi likuidasi?

\section{I.3. Tujuan Penelitian}

1. Untuk memahami tanggung jawab bank terhadap nasabah penyimpan atas simpanannya yang tidak dijamin oleh Lembaga Penjamin Simpanan

2. Untuk memahami upaya bank dalam penyelesaian simpanan nasabah yang simpanannya melebihi jumlah penjaminan oleh Lembaga Penjamin Simpanan setelah terjadi likuidasi.

\section{Isi Makalah}

\subsection{Metode Penelitian}

Jenis penelitian yang digunakan dalam penulisan skripsi ini adalah penelitian hukum yuridis empiris adalah terdiri dari penelitian terhadap identifikasi hukum dan efektivitas hukum. ${ }^{4}$ sehingga dalam penyusunannya dilakukan dengan penelitian lapangan yang memanfaatkan data-data primer dari hasil wawancara dan observasi yang didukung dengan sumber primer, sumber data sekunder, maupun sumber data tersier. Pendekatan undang-undang dilakukan dengan menelaah semua undangundang dan regulasi yang bersangkutan. Pendekatan fakta dilakukan dengan meneliti kenyataan atau fakta-fakta yang ada di lapangan mengenai penjaminan simpanan nasabah pada bank yang tidak dijamin oleh Lembaga Penjamin Simpanan ketika bank tersebut mengalami likuidasi. Pendekatan konseptual dilakukan dengan berpijak pada konsep-konsep, pandangan dan doktrin yang berkembang dalam ilmu hukum sekaligus

4 Bambang Sunggono, 2010, Metode Penelitian Hukum, Rajawali Press, Jakarta. h.41. 
mengetahui penerapan dalam praktik dan putusan-putusan hukum. ${ }^{5}$

\subsection{Hasil Analisa}

\subsubsection{Tanggung Jawab Bank atas Simpanan Nasabah yang Tidak Dijamin oleh Lembaga Penjamin Simpanan}

Tanggung jawab dalam arti hukum adalah tanggung jawab yang benar-benar terkait dengan hak dan kewajiban, bukan dalam arti tanggung jawab yang dikaitkan dengan gejolak jiwa sesaat atau yang tidak disadari oleh akibatnya. Secara umum, prinsip tanggung jawab dalam hukum dapat dibedakan sebagai berikut:

1. Prinsip Tanggung Jawab Berdasarkan Unsur Kesalahan

2. Prinsip Praduga Untuk Selalu Bertanggung Jawab

3. Prinsip Praduga Untuk Tidak Selalu Bertanggung Jawab

4. Prinsip Tanggung Jawab Mutlak

5. Prinsip Tanggung Jawab Dengan Pembatasan. ${ }^{6}$

Bank gagal atau dalam hal ini bank yang dilikuidasi memiliki kewajiban yang harus dilakukan berdasarkan Pasal 54 ayat (1) Undang-Undang Nomor 24 Tahun 2004 tentang Lembaga Penjamin Simpanan menentukan:

Pembayaran kewajiban bank kepada para kreditur dari hasil pencairan dan/atau penagihan sebagaimana dimaksud dalam Pasal 53 dilakukan dengan urutan sebagai berikut:

${ }^{5}$ Bahder Johan Nasution, 2016, Metode Penelitian Hukum, Mandar Maju, Bandung. Hlm.5

6 Celina Tri Siwi Kristiyanti, 2008 Hukum Perlindungan konsumen, PT. Sinar Grafika, Jakarta. Hlm.94 
a. penggantian atas talangan pembayaran gaji pegawai yang terutang;

b. penggantian atas pembayaran talangan pesangon pegawai;

c. biaya perkara di pengadilan, biaya lelang yang terutang, dan biaya operasional kantor;

d. biaya penyelamatan yang dikeluarkan oleh LPS dan/atau pembayaran atas klaim Penjaminan yang harus dibayarkan oleh LPS;

e. pajak yang terutang;

f. bagian Simpanan dari nasabah penyimpan yang tidak dibayarkan penjaminannya dan Simpanan dari nasabah penyimpan yang tidak dijamin; dan

g. hak dari kreditur lainnya.

Berdasarkan hasil wawancara dengan (ibu I Gusti Ayu Kesumawati sebagai Kepala Kas pada BPR Swasad Artha) pada tanggal (tanggal 16 Januari 2019) menutut beliau, bank yang dalam hal ini telah dicabut izin usahanya harus melakukan pengembalian dana simpanan nasabah yang tidak mendapatkan jaminan oleh Lembaga Penjamin Simpanan. Simpanan yang dikembalikan yaitu kelebihan simpanan nasabah dari $\mathrm{Rp}$ 2.000.000.000,00 (dua miliar rupiah) yang merupakan jumlah maksimum penjaminan oleh Lembaga Penjamin Simpanan, yang merupakan diluar tanggungan dari LPS. Adapun jumlah nasabah yang memiliki simpanan yang tidak mendapatkan jaminan oleh LPS yaitu sebesar 1,2 persen dari total nasabah penyimpan yang menyimpan dana pada BPR Swasad Artha yang memiliki dana simpanan melebihi dari Rp 2.000.000.000,00 (dua miliar rupiah). Kelebihan dana simpanan dari Rp 2.000.000.000,00 (dua miliar rupiah) menjadi tanggung jawab bank didalam pengembaliannya. 
Lebih lanjut ibu I Gusti Ayu Kesumawati menjelaskan bahwa menurut beliau, yaitu bagi nasabah yang mempunyai dana dibawah Rp. 2.000.000.000,00 (dua miliar rupiah) sampai maksimal Rp. 2.000.000.000,00 (dua miliar rupiah), segera mendapatkan dananya kembali sepanjang telah memenuhi persyaratan yang telah ditetapkan oleh Undang-Undang LPS. LPS telah menyelesaikan tanggungjawabnya di dalam membayarkan dana nasabah hingga Rp. 2.000.000.000,00 (dua miliar rupiah) yang menjadi tanggungjawabnya berdasarkan Peraturan Perundang-undangan yang berlaku bagi simpanan nasabah yang dinyatakan layak bayar.

Menurut ibu I Gusti Ayu Kesumawati pada tanggal (16 Januari 2019) sebagai bentuk pertanggungjawaban kepada nasabah, BPR Swasad Artha melakukan pengembalian dana secara bertahap kepada nasabah-nasabahnya yang simpanannya tidak dijaminkan oleh LPS, yaitu kelebihan simpanan dari jumlah maksimun yang dijamin oleh LPS dan nasabahnasabah tersebut telah mengajukan pengembalian dana terhitung sejak dinyatakan likuidasi dan dana yang dipakai merupakan dana hasil penjualan aset bank yang merupakan bentuk pertanggungjawaban dari pengurus serta pemegang saham pada BPR Swasad Artha. Dalam kasus BPR Swasad Artha yang dilikuidasi, tidak ada dana nasabah yang tidak dibayarkan atau tidak dikembalikan oleh pihak bank, karena aset atau kekayaan bank masih mencukupi untuk pengembalian dana nasabah yang dalam hal ini tidak mendapatkan jaminan dari Lembaga Penjamin Simpanan.

Bentuk tanggung jawab BPR Swasad Artha yaitu bank bertanggung jawab berdasarkan prinsip tanggung jawab dengan pembatasan karena bank bertanggung jawab hanya sebatas dana 
simpanan nasabah yang tidak dijamin oleh LPS, dalam hal ini yaitu kelebihan simpanan nasabah dari Rp2.000.000.000,00 (dua miliar rupiah) yang menjadi tanggung jawab bank, karena simpanan nasabah lainnya sudah dijamin oleh Lembaga Penjamin Simpanan. Pembatasan disini yang dimaksud yaitu bank hanya bertanggung jawab atas kelebihan simpanan nasabah dari jumlah maksimum yang telah dijamin oleh LPS sesuai dengan peraturan perundang-undangan yang berlaku.

\subsubsection{Penyelesaian Simpanan yang Tidak Dijamin oleh Lembaga Penjamin Simpanan}

Proses penyerahan hak nasabah jika bank dalam likuidasi terbagi dalam 2 (dua) tahapan yaitu :

1. Selama pelaksanaan masih berlangsung, pembayaran kewajiban kepada kreditur berasal dari hasil pencairan aset atau penagihan piutang yang dilakukan secara bertahap selama masa likuidasi atau sekaligus pada akhir pelaksanaan likuidasi.

2. Pelaksanaan likuidasi telah berakhir, setelah pelaksanaan likuidasi berakhir dimungkinkan terjadi pembayaran kepada para kreditur apabila :

a. Kreditur belum mengambil bagiannya sampai batas waktu setelah tanggal pembayaran terakhir dan berakhirnya pelaksanaan likuidasi.

b. Terdapat pembayaran oleh para debitur setelah berakhirnya pelaksanaan likuidasi. ${ }^{7}$

${ }^{7}$ Made Ciria Angga Mahendra, Yuwono, 2015, Perlindungan Hukum Bagi Nasabah Dalam Likuidasi Bank, Jurnal Hukum Udayana, 15 Agustus 2015. url: https://www.e-jurnal.com/2015/08/perlindungan-hukum-bagi-nasabahdalam.html Diakses pada tanggal 29 Januari 2019, pukul 12.45. 
Upaya penyelesaian antara nasabah dengan bank yang dalam hal ini yaitu BPR Swasad Artha, adapun macam-macam penyelesaian sengketa yaitu melalui upaya litigasi (melalui pengadilan) dan non litigasi (diluar pengadilan).

Merujuk pada Pasal 1 angka 10 Undang-Undang Nomor 30 Tahun 1999 tentang Arbitrase dan Alternatif Penyelesaian Sengketa, APS terdiri dari penyelesaian di luar pengadilan dengan menggunakan metode konsultasi, negosiasi, mediasi, konsiliasi atau penilaian ahli. Jenis-jenis APS tersebut dapat dipilih oleh para pihak untuk menyelesaian persengketaan perdata yang mereka alami.

Penyelesaian sengketa secara non litigasi adalah penyelesaian sengketa atau perkara diluar pengadilan dengan cara sengketa alternatif. Penyelesaian ini dapat ditempuh dengan cara mediasi, konsultasi, konsiliasi, negosiasi, dan penilaian ahli. ${ }^{8}$

3. Berdasarkan hasil wawancara dengan (ibu I Gusti Ayu Kesumawati sebagai Kepala Kas pada BPR Swasad Artha) pada tanggal (tanggal 21 Januari 2019) Upaya yang dilakukan oleh BPR Swasad Artha di dalam menyelesaikan permasalahan dengan melakukan upaya negosiasi. Negosiasi ini disepakati oleh kedua belah pihak di dalam menyelesaiakan permasalahan. Hal ini dikarenakan pihak bank selalu menunjukkan itikad baik kepada nasabah dan mengembalikan dana nasabahnya selama pelaksanaan likuidasi masih berlangsung, yaitu pengembalian dana nasabah berasal dari hasil pencairan aset atau penagihan piutang yang dilakukan secara

8 I Ketut Artadi dan Dewa Nyoman Rai Asmara Putra, 2010, Implementasi Ketentuan-Ketentuan Hukum Perjanjian ke dalam Perancangan Kontrak, Udayana University Press, Denpasar, h. 10. 
bertahap selama masa likuidasi hingga akhir proses likuidasi.

Lebih lanjut ibu I Gusti Ayu Kesumawati menjelaskan pada tanggal (21 Januari 2019) bahwa langkah-langkah negosiasi yang dilakukan dengan beberapa tahpan menghasilkan kesepakatan bagi para pihak bahwa:

1. Bank meminta jangka waktu untuk melakukan pengembalian dana kepada nasabahnya melalui Tim Likuidasi.

2. Bank berjanji akan mengembalikan dana nasabah secara bertahap selama masa likuidasi kepada nasabah yang memiliki sisa dana pasa bank melalui Tim Likuidasi.

Negosiasi diajukan oleh pihak bank kepada nasabahnya sehingga mendapatkan kesepakatan hasil musyawarah antara bank dengan nasabah penyimpan yang dalam hal ini sudah menyepakati hal yang disampaikan oleh bank, karena nasabah memaklumi hal tersebut dan memberikan jangka waktu kepada bank di dalam mengembalikan dana mereka secara bertahap.

Nasabah yang sudah mengajukan permohonan pengembalian dana akan segera dilakukan pengembalian namum tetap harus menunggu hingga proses penjualan aset terselesaikan, Hal tersebut juga sudah dijelaskan oleh pihak bank kepada nasabahnya. Sehingga pihak bank dapat mengembalikan dana nasabah-nasabah yang masih tersimpan di bank. Hingga akhir proses likuidasi selesai, pengembalian dana nasabah tidak terdapat kendala, karena pihak bank mengembalikan sisa simpanan nasabah sesuai kesepakatan negosiasi, sehingga tidak ada pihak yang melakukan upaya litigasi atau menempuh jalur pengadilan atau upaya litigasi. 


\section{III.PENUTUP}

\subsection{Kesimpulan}

Dari uraian-uraian yang telah dikemukakan, maka dapat ditarik kesimpulan sebagai berikut:

1. Tanggung jawab Bank terhadap simpanan nasabah pada BPR Swasad Artha yang melebihi jumlah maksimal penjaminan oleh LPS sehingga tidak dijamin oleh LPS, dikembalikan oleh bank secara bertahap hingga hasil penjualan aset dan pemberesan yang dilakukan oleh Tim Likuidasi kepada nasabah penyimpan. Bank bertanggungjawab atas kelebihan simpanan dari batas maksimum penjaminan oleh LPS dengan berdasarkan atas prinsip tanggung jawab dengan pembatasan, yaitu bank hanya bertanggung jawab sebatas apa yang telah diatur di dalam peraturan perundang-undangan.

2. Upaya bank dalam penyelesaian simpanan nasabah yang dalam hal ini tidak mendapatkan jaminan oleh LPS, faktanya diselesaikan melalui penyelesaian sengketa di luar pengadilan (non litigasi). Penyelesaian non litigasi yang dilakukan oleh BPR Swasad Artha dengan nasabah penyimpan yaitu dengan cara negosiasi, dimana bank melakukan negosiasi yang telah disepakati oleh para pihak, berupa:

1. Bank meminta jangka waktu untuk melakukan pengembalian dana kepada nasabahnya melalui Tim Likuidasi

2. Bank berjanji akan mengembalikan dana nasabah secara bertahap selama masa likuidasi kepada 
nasabah yang memiliki sisa dana pada bank melalui Tim Likuidasi.

\subsection{Saran}

Adapun saran yang dapat disampaikan sesuai dengan penelitian ini adalah sebagai berikut :

1. Untuk menghindari adanya simpanan nasabah yang tidak mendapatkan jaminan, hendaknya pihak bank dengan nasabah membuat suatu perjanjian di awal yang nantinya digunakan sebagai acuan apabila terjadi suatu permasalahan hingga menyebabkan bank dilikuidasi, dapat diselesaikan berdasarkan perjanjian yang telah dibuat sehingga tidak merugikan pihak nasabah maupun pihak bank.

2. Para pihak hendaknya melakukan upaya penyelesaian terhadap simpanan nasabah yang tidak dijamin oleh Lembaga Penjamin Simpanan apabila terjadi likuidasi bank, melalui upaya penyelesaian non litigasi dengan melakukan negosiasi sehingga tidak merugikan pihak nasabah.

\section{Daftar Pustaka}

\section{A. Buku}

Bahder Johan Nasution, 2016, Metode Penelitian Hukum, Mandar Maju, Bandung.

Bambang Sunggono, 2010, Metode Penelitian Hukum, Rajawali Press, Jakarta.

Celina Tri Siwi Kristiyanti, 2008 Hukum Perlindungan konsumen, PT. Sinar Grafika, Jakarta.

I Ketut Artadi dan Dewa Nyoman Rai Asmara Putra, 2010, Implementasi Ketentuan-Ketentuan Hukum Perjanjian ke dalam Perancangan Kontrak, Udayana University Press, Denpasar. 
Jonker Sihombing, 2010, Penjamin Simpanan Nasabah Perbankan, Alumni, Bandung.

Kusumaningtuti SS, 2008, Peranan Hukum Dalam Penyelesaian Krisis Perbankan di Indonesia, Rajawali Pers, Jakarta.

\section{B. Jurnal Ilmiah}

Made Ciria Angga Mahendra, Yuwono, 2015, Perlindungan Hukum Bagi Nasabah Dalam Likuidasi Bank, Jurnal Hukum Udayana, 15 Agustus 2015.

url: $\quad$ https://www.e-jurnal.com/2015/08/perlindunganhukum-bagi-nasabah-dalam.html Diakses pada tanggal 29 Januari 2019, pukul 12.45.

Ni Made Dasri Librayanti, Made Mahartayasa, 2014, Kewenangan Lembaga Penjamin Simpanan dalam Likuidasi Bank, Jurnal Hukum Udayana, Vol. 02, No. 02,Februari 2014.

Url: https:/ / www.e-jurnal.com/2014/12/kewenanganlembaga-penjamin-simpanan.html

Diakses pada tanggal 26 Februari 2019, pukul 17.30

\section{Peraturan perundang-undangan}

Indonesia, Undang-Undang Nomor 10 Tahun 1998 tentang Perubahan atas Undang-Undang Nomor 7 Tahun 1992 tentang Perbankan, (Lembaran Negara Republik Indonesia Tahun 2008 Nomor 38, Tambahan Lembaran Negara Republik Indonesia Nomor 4824).

Indonesia, Undang-Undang Republik Indonesia Nomor 24 Tahun 2004 tentang Lembaga Penjamin Simpanan, (Lembaran Negara Republik Indonesia Tahun 2004 Nomor 96, Tambahan Lembaran Negara Republik Indonesia Nomor 4420). 